\title{
Exopolysaccharide Production Is Required for Biofilm Formation and Plant Colonization by the Nitrogen-Fixing Endophyte Gluconacetobacter diazotrophicus
}

\author{
Carlos H. S. G. Meneses, ${ }^{1,2}$ Luc F. M. Rouws, ${ }^{2}$ Jean L. Simões-Araújo, ${ }^{2}$ Marcia S. Vidal, ${ }^{2}$ and \\ José I. Baldani ${ }^{2}$ \\ ${ }^{1}$ Programa de Biotecnologia Vegetal, Universidade Federal do Rio de Janeiro, Centro de Ciências da Saúde, Bloco K, \\ 21941-590, Ilha do Fundão, Rio de Janeiro, RJ, Brazil; ²Laboratório de Genética e Bioquímica, Embrapa Agrobiologia, \\ Rodovia BR 465, km 07, 23890-000, Seropédica, RJ, Brazil
}

Submitted 18 May 2011. Accepted 24 July 2011.

\begin{abstract}
The genome of the endophytic diazotrophic bacterial species Gluconacetobacter diazotrophicus PAL5 (PAL5) revealed the presence of a gum gene cluster. In this study, the gumD gene homologue, which is predicted to be responsible for the first step in exopolysaccharide (EPS) production, was insertionally inactivated and the resultant mutant (MGD) was functionally studied. The mutant MGD presented normal growth and nitrogen $\left(\mathrm{N}_{2}\right)$ fixation levels but did not produce EPS when grown on different carbon sources. MGD presented altered colony morphology on soft agar plates $(0.3 \%$ agar $)$ and was defective in biofilm formation on glass wool. Most interestingly, MGD was defective in rice root surface attachment and in root surface and endophytic colonization. Genetic complementation reverted all mutant phenotypes. Also, the addition of EPS purified from culture supernatants of the wild-type strain PAL5 to the mutant MGD was effective in partially restoring wild-type biofilm formation and plant colonization. These data provide strong evidence that the PAL5 gumD gene is involved in EPS biosynthesis and that EPS biosynthesis is required for biofilm formation and plant colonization. To our knowledge, this is the first report of a role of EPS in the endophytic colonization of graminaceous plants by a nitrogen-fixing bacterium.
\end{abstract}

Gluconacetobacter diazotrophicus is a diazotrophic bacterium found colonizing, in high numbers, the internal tissues of plants such as sugarcane (Cavalcante and Döbereiner 1988), sweet potato (Ipomoea batatas), pineapple (Ananas comosus) (Baldani and Baldani 2005), and rice (Oryza sativa) (Muthukumarasamy et al. 2007). In addition to the ability to fix $\mathrm{N}_{2}$ in association with sugarcane plants, it has been demonstrated that this bacterium has other interesting physiological abilities such as phytohormone production (Sevilla et al. 2001), phosphate and zinc solubilization, and control of phytopathogens (Saravanan et al. 2007). The inability to isolate G. diazotrophicus from soil between rows of sugarcane plants in Brazil and the low survival rates when artificially inoculated in soil (Baldani et al. 1997)

Corresponding author: J. I. Baldani; Telephone: +55-21-3441-1555; Email: ibaldani@cnpab.embrapa.br

* The $e$-Xtra logo stands for "electronic extra" and indicates that four supplementary figures are published online. supports its endophytic nature, in contrast to other associative bacteria such as Azospirillum spp., which are predominantly rhizosphere inhabiting and can be isolated from soil (Steenhoudt and Vanderleyden 2000).

The infection and colonization processes of $G$. diazotrophicus were initially studied in micropropagated sugarcane plants (James et al. 1994, 2001; Reis et al. 1999). These authors proposed that this bacterium first colonized the root and lower stem epidermal surfaces and then used root tips, sites of lateral root emergence, and stomata to enter the sugarcane plant internal tissues. Later, microscopy studies have also been extended to seed plants such as rice (Rouws et al. 2010), which was also shown to be endophytically colonized. Previous studies with G. diazotrophicus have been conducted using micropropagated sugarcane plants (Reis et al. 1999). However, the micropropagation technique is highly time consuming and laborious. In fact, hydroponically grown rice seedlings have proven to be a valuable model system for $G$. diazotrophicus-plant interactions, allowing rapid assays and presenting low autofluorescence, which facilitates microscopy studies (Rouws et al. 2010). Nevertheless, the molecular mechanisms that enable $G$. diazotrophicus to colonize its host plants remain little studied.

A successful endophytic association commonly involves an initial phase of bacterial attachment to the root surface. The subsequent endophytic colonization is believed to involve bacterial cell-wall-degrading enzymes (CWDE) such as endoglucanases and pectinases (Compant et al. 2010). However, as was also observed for the kallar grass endophytic bacteria Azoarcus sp. strain BH72 (Krause et al. 2006), CWDE are scarce on the PAL5 genome, which contains only a single endoglucanase gene, designated as eglA (GenBank accession number YP_001602781) (Bertalan et al. 2009). Nevertheless, emerging lateral plants roots, which originate from the pericycle, rupture the endodermis, the cortex, and the epidermis cell layers of the main root, causing cracks which may allow for passive entrance of bacteria, a process also known as crack entry (Compant et al. 2010; James and Olivares 1998).

The root attachment process has been studied in detail for the plant growth-promoting bacterial species Azospirillum brasilense. This species harbors surface-colonizing strains, such as Sp7, which is not found inside plants, as well as strains such as $\mathrm{Sp} 245$, capable of endophytically colonizing host plants (Assmus et al. 1995; Hartmann et al. 1995). In 1991, Michiels and associates (1991) distinguished two phases in the surface 
attachment of the plant rhizosphere inhabiting A. brasilense Sp7 to roots of wheat plants. i) The initial weak binding of bacterial cells to the root surface, which is mediated by flagella and other proteins, was named the "adsorption" phase. "Adsorbed" cells could be released from the root surface by intense shaking or vortexing but not by gentle rinsing. ii) A subsequent irreversible attachment phase was named "anchoring", during which the bacteria become irreversibly bound to the root surface. This anchoring phase was shown to require exopolysaccharide (EPS) production.

EPS are produced by a variety of bacteria, including nitrogen-fixing bacteria from genera such as Azoarcus, Rhizobium, Azospirillum, Sinorhizobium, Burkholderia, and Bradyrhizobium (Fitriyanto et al. 2011; Hallack et al. 2010; Hurek and Reinhold-Hurek 2003; Morris and González 2009; Skorupska et al. 2006; Valverde et al. 2008). In these bacteria, EPS, along with flagella, pili, bacterial exudates, and signaling molecules, have been shown to be important for the formation of biofilms and the first steps of the colonization process (RodríguezNavarro et al. 2007). In rhizobium-legume interactions, EPS are involved in the bacterial invasion of the plant, nodule development, bacterial release from the infection threads, bacteroid development, and protection against plant antimicrobial compounds (Skorupska et al. 2006). In addition, EPS contribute to growth and survival of bacteria within the plant, helping in the colonization process and creating a favorable microenvironment where EPS may act as a barrier against plant defense mechanisms (Dow et al. 2000; Rinaudi and Giordano 2010). However, to our knowledge, the role of EPS in the physiology of and plant colonization by nitrogen-fixing endophytic bacteria such as $G$. diazotrophicus has not been reported.

The production of EPS is a stepwise process in which glycosyltransferases sequentially link sugar residues to a lipid carrier to form a sugar polymer. The first step in bacterial EPS synthesis is the transfer of a phosphate-1-sugar to a phosphorylated undecaprenol (lipid carrier), which is carried out by an undecaprenyl-phosphate glycosyl-1-phosphate transferase (UndPGPTs) (EC 2.7.8.-) (Whitfield and Valvano 1993). The inactivation of genes encoding UndPGPTs (gumD gene homologues) abolishes EPS production and related phenotypes such as virulence, pigmentation, resistance to abiotic factors, biofilm formation, and adhesion to surfaces in phytopathogenic Xanthomonas spp. (Chou et al. 1997; Katzen et al. 1996; Kemp et al. 2004; Kim et al. 2009; Rigano et al. 2007).

The genome of PAL5 contains a variety of genes probably involved in bacteria-plant interactions, such as genes coding for surface proteins (flagella and pili), genes involved in synthesis of capsular polysaccharide and lipopolysaccharide, and gum genes (Bertalan et al. 2009). The 15 gum genes are present on three putative operons on a single $19.7-\mathrm{kb}$ cluster and their function in PAL5 has not been studied.

In this study, evidence is provided that the gumD gene is essential for EPS production by PAL5 and that EPS production by this bacterium is determinant for biofilm formation and plant colonization.

\section{RESULTS}

Comparison of the gum gene cluster from PAL5 to homologous genes on other bacterial genomes.

Among bacterial species that have a complete DNA sequence available for gum gene clusters, the PAL5 gum genes are most similar to the ace cluster from G. xylinus, with respect to both most individual gene products and their organization (Fig. 1) (Ishida et al. 2002). No homologues of the gum genes were found on the Gluconobacter oxydans genome which, like Gluconacetobacter xylinus, is phylogenetically related to $G$. diazotrophicus. Furthermore, four PAL5 gum genes (gumE, gumJ, gumK, and eglA) that were absent in G. xylinus showed similarity to genes from the phylogenetically distant diazotrophic endophyte Azoarcus sp. strain BH72 (Krause et al. 2006) and from the phytopathogens Xanthomonas campestris pv. campestris and Xylella fastidiosa 9a5c. In several organisms, such as G. xylinus and Xanthomonas spp., a relation has been observed between the number of sugar transferases and the repeated oligosaccharide unit that constitutes the mature EPS (Colquhoun et al. 1995; Griffin et al. 1996; Jansson et al. 1975). Therefore, based on the presence of seven sugar transferase gene homologues $(\mathrm{gumD}$, gumM, gumH, gumK, ace $Q$, ace $P$, and a novel glycosyltransferase annotated as GDI_2536), the EPS produced by PAL5 is most probably composed of a heptasaccharide repeat unit.

\section{Tn5 insertional inactivation of the PAL5 gumD gene and genetic complementation of the resultant mutant MGD.}

In order to investigate the role of gumD in EPS biosynthesis by PAL5, the gumD gene was interrupted by the insertion of a commercial Tn5 transposon, generating the mutant MGD. This mutant was molecularly validated by Southern blot analyses and by inverse polymerase chain reaction (IPCR), followed by sequencing, which confirmed that the Tn5 insertion occurred after base pair position 410 of the gumD gene (data not shown) (Supplementary Fig. 1).

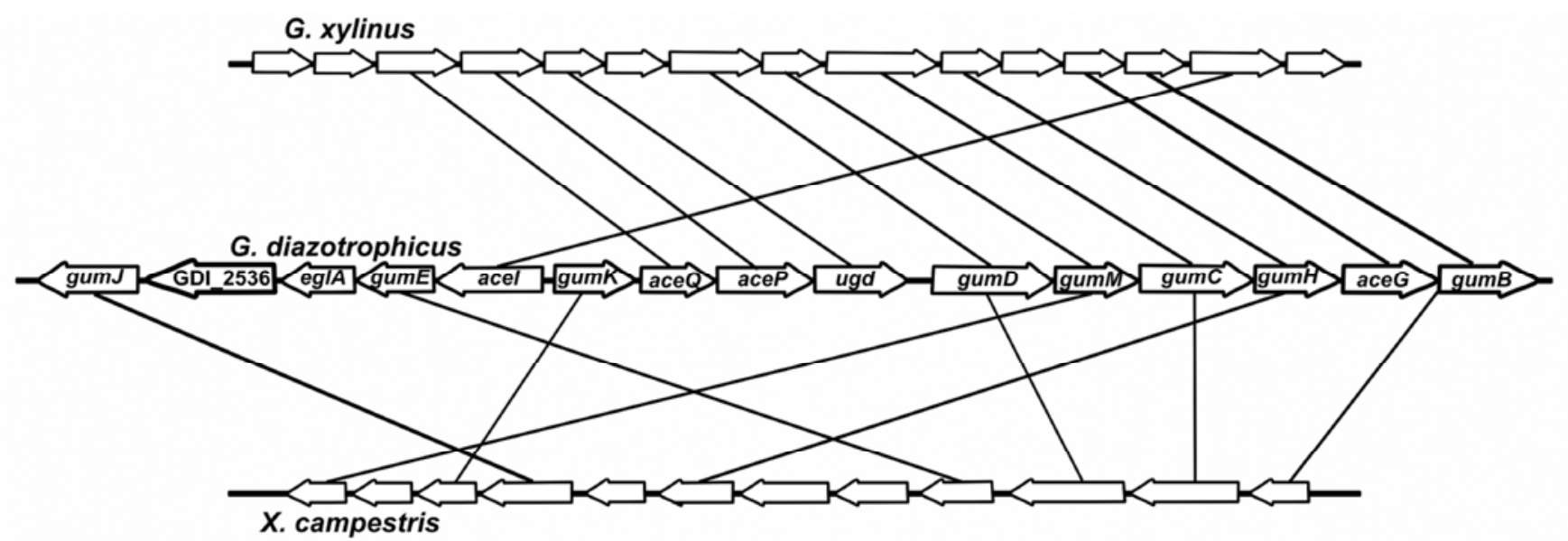

Fig. 1. Comparison of the exopolysaccharide gene clusters of Gluconacetobacter diazotrophicus PAL5, G. xylinus, and Xanthomonas campestris. The architecture of the gum cluster of G. diazotrophicus PAL5 was compared with the G. xylinus ace cluster and the X. campestris gum cluster. Orthologous genes were identified and are connected by lines. 
For genetic complementation, the gumD gene, including its putative promoter region, was cloned and introduced into the genome of the MGD mutant by homologous recombination, generating the cis-complemented strain CMGD. Southern blot analysis confirmed the integration of the pGUMD plasmid into the genome by single homologous recombination, thus restoring the wild-type gumD locus. A scheme of the mutagenesis and genetic complementation strategies is available as supplementary material.

\section{General growth features of the mutant MGD.}

Growth rates, the capacity to form $\mathrm{N}_{2}$-fixing aerotactic pellicles in $\mathrm{N}$-free semisolid medium, and the acetylene reduction activities (nitrogenase activity) were similar for PAL5, the MGD, and the complemented mutant CMGD (data not shown), thus indicating that the interruption of the gumD gene did not affect general growth features.

Depending on the consistency of the culture medium, the morphology of MGD colonies formed on plates was affected when compared with the wild type. Although MGD colonies were similar to PAL5 colonies on plates containing 1.5 and $0.7 \%$ agar, the morphology was different at lower agar concentrations $(0.3 \%)$. Under these circumstances, PAL5 formed wetlooking colonies, probably due to EPS production, while MGD colonies were "dry" (data not shown). The complemented mutant CMGD formed wild-type colonies, therefore suggesting that the gumD gene is involved in the determination of colony structure.

\section{EPS production is severely affected in the mutant MGD.}

The in vitro production of EPS by $G$. diazotrophicus strains grown on different carbon sources was investigated. Total carbohydrates from culture supernatants that could be precipitated with ethanol were quantified and assumed to represent EPS. Analysis of PAL5, MGD, and CMGD supernatant polysaccharides showed that mannitol was the best carbon source to produce large quantities of EPS (Fig. 2). The lowest production of EPS by PAL5 strain was observed with glucose, whereas fructose and sucrose led to intermediate quantities of EPS (Fig. 2). The production of EPS by the MGD mutant was abolished, or at least greatly reduced, for all tested carbon sources. Nevertheless, some carbohydrate precipitated for the MGD mutant,

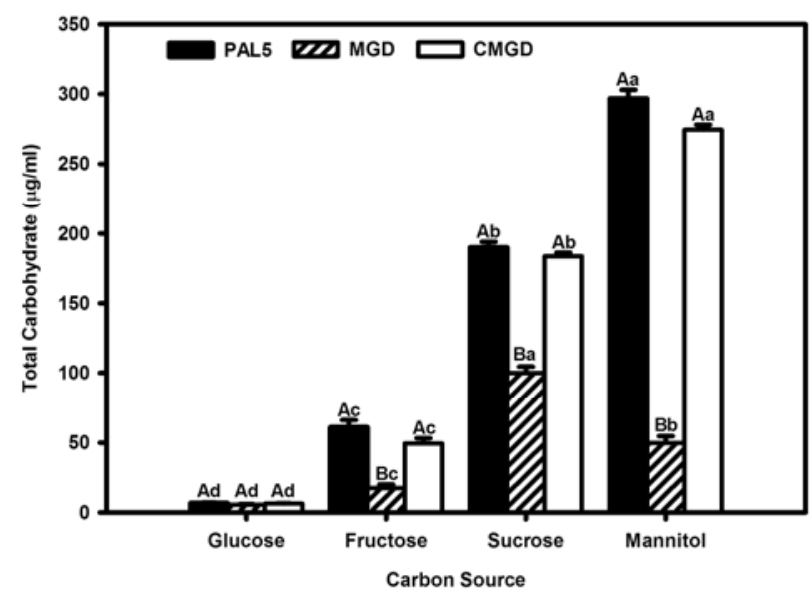

Fig. 2. Quantification of exopolysaccharide (EPS) production by the wildtype PAL5, the gumD mutant MGD, and the complemented mutant CMGD grown on different carbon sources. EPS from culture supernatants were precipitated with ethanol and dissolved in water; then, the total carbohydrates were quantified by the phenol sulfuric method (Dubois et al. 1956). Bars represent the standard error $(n=3)$. Different letters indicate statistical difference (Tukey's test, $P<0.05$ ). Lower- and uppercase letters were used to compare the carbon sources and the strains, respectively. especially when using mannitol and sucrose as carbon sources. However, sucrose and mannitol are soluble in water-ethanol mixtures to a limited extent (Bouchard et al. 2007; Quesada et al. 1993). Therefore, unmetabolized sugar is probably responsible for a large part of this precipitate. Accordingly, the precipitate observed for MGD, when using sucrose as the carbon source, consisted of typical sucrose-like crystals. Also, the MGD mutant may produce some polysaccharide, because PAL5 is known to encode and express an extracellular levansucrase involved in the production of levan, a fructose polymer, using sucrose as a precursor (Hernández et al. 1995; TapiaHernández et al. 2000). CMGD produced wild-type levels of EPS for all carbon sources. Therefore, these data strongly suggest that the gumD gene is involved in EPS production by PAL5 grown on different carbon sources.

\section{EPS production is essential}

for biofilm formation by $\boldsymbol{G}$. diazotrophicus on glass wool.

The capacity of the mutant MGD to form biofilm on glass wool substrate in liquid culture was investigated with glucose or mannitol as the carbon source. Independently of the carbon source, PAL5 and CMGD formed biofilms that could be stained with crystal violet (Fig. 3A; Supplementary Fig. 2). In contrast, no biofilm formation was observed for MGD (Fig. $3 \mathrm{~A})$. We wondered if the defect in EPS production caused by the gumD mutation could be circumvented by the addition of purified EPS produced by the PAL5 strain. Therefore, biofilm formation on glass wool by MGD was studied after the addition of different concentrations of purified EPS to the growth medium at the time of inoculation. The amount of biofilm by
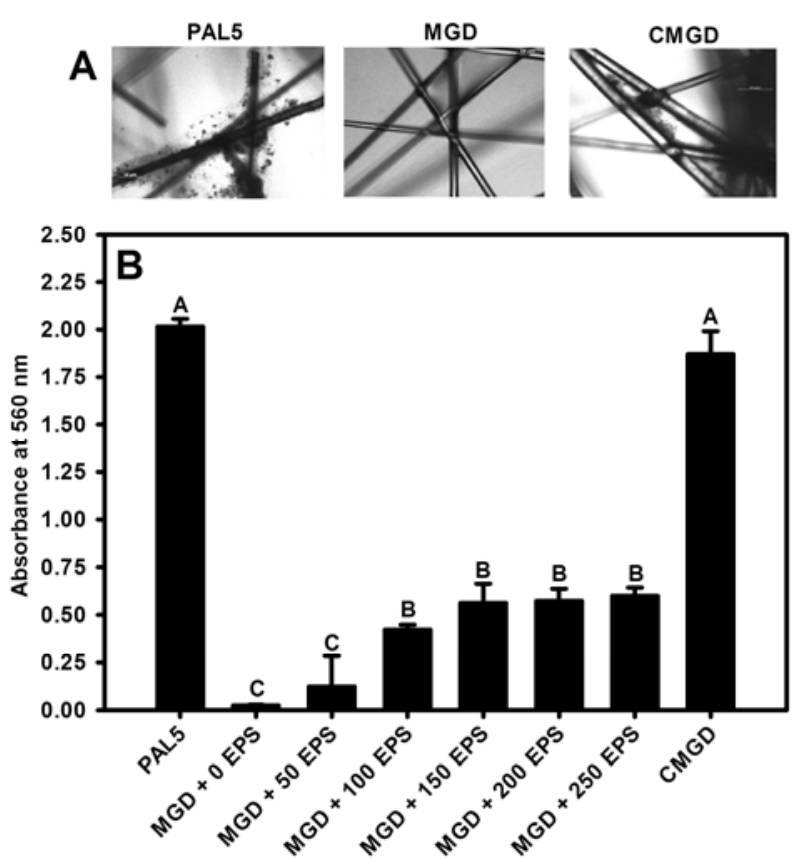

Fig. 3. Visualization and quantification of biofilms formed on glass wool by the wild-type PAL5, the gumD mutant MGD, and the complemented mutant CMGD. Cells were grown in modified LGI-P medium (Reis et al. 1994) for 3 days in the presence of glass wool. Then, biofilms were stained with crystal violet. A, Stained biofilms were visualized by light microscopy. B, Gluconacetobacter diazotrophicus strains were allowed to form biofilms on glass wool in the absence or presence of purified exopolysaccharide (EPS) from PAL5 supernatant. Final EPS concentrations are represented by numbers $(\mu \mathrm{g} / \mathrm{ml})$ below the $x$ axis. After incubation, crystal violet was extracted from stained biofilms with absolute ethanol and quantified by spectrophotometry (absorbance at $560 \mathrm{~nm}$ ). Bars represent the standard error $(n=3)$. Different letters indicate statistical difference (Tukey's test, $P<0.05$ ) 
MGD significantly increased after the addition of EPS in a dose-dependent fashion, although wild-type (PAL5) levels could not be attained (Fig. 3B). These data strengthen the evidence that the gumD gene is required for biofilm formation on glass wool through the production of EPS. The data also show that maximizing EPS production using mannitol instead of glucose as a carbon source does not affect the biofilm phenotype by PAL5.

\section{Dynamics of PAL5 attachment}

to roots of hydroponically grown rice seedlings.

EPS production may be important during attachment of plant-associated bacteria to the root surface. In a previous study, we demonstrated that rice seedlings can be endophytically colonized by PAL5, forming a useful model system, enabling rapid assays (Rouws et al. 2010). Therefore, we chose rice seedlings to study the dynamics of PAL5 attachment to roots in a way similar to that previously described for $A$. brasilense on wheat (Michiels et al. 1991). These authors evaluated the weak initial attachment (adsorption) phase in the absence of a carbon source, while irreversible attachment (anchoring) studies were conducted in the presence of a carbon source in order to maximize EPS production (Croes et al. 1993; Michiels et al. 1991). Similarly, the effect of the presence of a carbon source (mannitol) was also investigated in the present study. Briefly, in the presence or absence of mannitol, rice roots were incubated in the presence of a known number of PAL5 cells and, after different time intervals, cells that remained bound to rice roots after rinsing were considered to be attached. In the absence of mannitol, attachment of PAL5 cells to the roots started almost immediately and, at $15 \mathrm{~min}$ after inoculation, approximately $1 \times 10^{6}$ bacteria were attached. A maximum attachment peak occurred after $4 \mathrm{~h}$, corresponding to approximately $0.3 \%$ of the viable inoculated cells or approximately 3 $\times 10^{6} \mathrm{CFU}$ (Fig. 4). This relatively low attachment level in relation to the total number of inoculated cells is in accordance with observations from other studies. For example, between 0.4 and $3.5 \%$ of inoculated cells of Rhizobium spp. were found to attach to plant roots, depending on the assay (RodriguesNavarro et al. 2007).

In the present study, when mannitol was present, bacterial numbers obtained from rinsed inoculated roots were higher

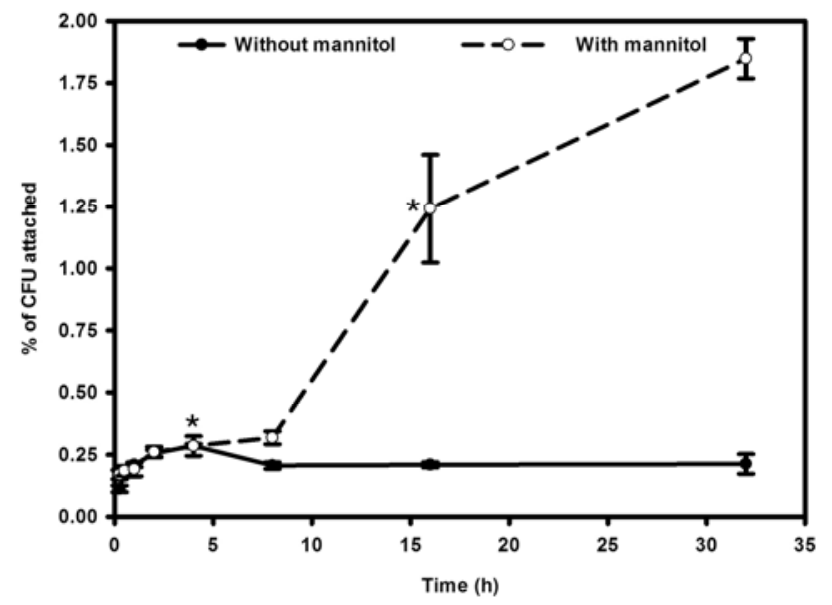

Fig. 4. Attachment of PAL5 cells to roots of rice seedlings in the presence or absence of mannitol. Attachment levels at different harvest time points after inoculation are presented as the proportion of adhering cells compared with the total number of inoculated cells (as percentage). Indicated harvest time points $(*)$ were used in subsequent experiments. Bars represent the standard error $(n=3)$. Different letters indicate statistical difference (Tukey's test, $P<0.05$ ). and increased during the entire course of the experiment. After $32 \mathrm{~h}$ of incubation, approximately $1.8 \%\left(2 \times 10^{7} \mathrm{CFU}\right)$ of the bacteria were attached. The sharpest increase occurred between 8 and $16 \mathrm{~h}$ after inoculation (Fig. 4). After $32 \mathrm{~h}$, no bacteria could be isolated from superficially sterilized plants, showing that endophytic colonization was not yet established at this time point. These results showed that the presence of the carbon source mannitol had a great stimulatory effect on attachment of PAL5 cells to rice roots, possibly by inducing EPS production. No significant attachment was observed when seedlings were inoculated with Escherichia coli DH10B, which was used as negative a control (data not shown).

\section{The mutant MGD is deficient in attachment to rice roots.}

To evaluate the role of EPS during the attachment process, the root surface attachment of the strains PAL5, MGD, and CMGD was investigated in more detail at 4 and $16 \mathrm{~h}$ after inoculation. In these experiments, the strength of attachment of the bacteria to the roots (as determined after rinsing or vortexing of roots) and the effect of the presence or absence of mannitol were evaluated. This experiment confirmed the positive effect of mannitol on PAL5 attachment (PAL5, rinse) (Fig. 5). It also showed that, after $4 \mathrm{~h}$ of incubation in the absence of mannitol, PAL5 cells could be quantitatively removed from roots by vortexing, whereas this was not the case in the presence of mannitol, indicating that the presence of mannitol stimulated irreversible attachment, probably by stimulating EPS production (Fig. 5). After $16 \mathrm{~h}$ of incubation, irreversible attachment also occurred in the absence of mannitol, although the number of bound cells in the presence of mannitol was much higher (Fig. 5). In contrast, the mutant MGD did not attach to the roots under any circumstances, whereas the complemented strain CMGD displayed similar binding characteristics to PAL5 (Fig. 5). Because mannitol and glucose were shown to be the best and worst carbon source for EPS production, respectively (Fig. 2), we also evaluated irreversible attachment levels in the presence of glucose instead of mannitol at $16 \mathrm{~h}$ after inoculation (Supplementary Fig. 3). The results

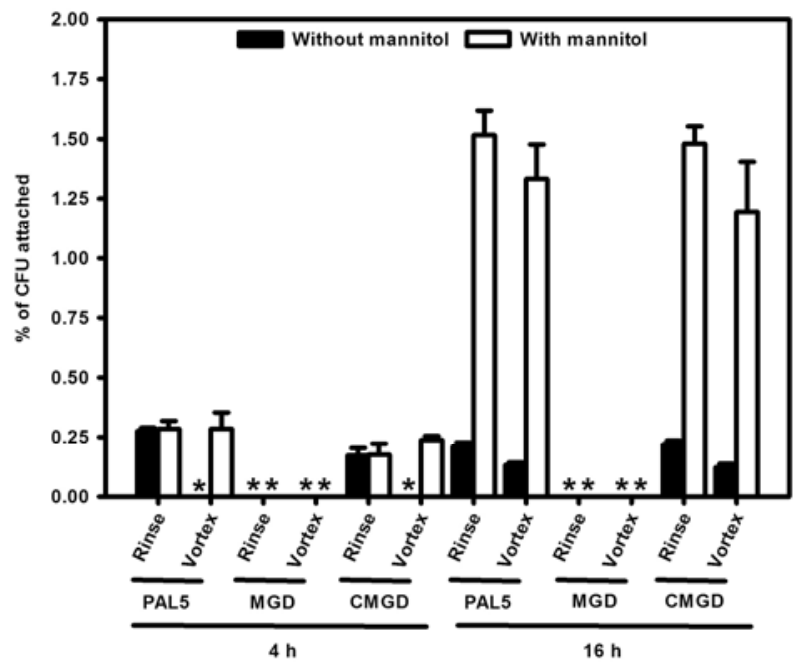

Fig. 5. Weak and irreversible attachment phases of PAL5, MGD, and CMGD cells to the surface of rice seedlings. Attachment levels by the respective strains were evaluated after 4 and $16 \mathrm{~h}$ in the absence or presence $(0.5 \%)$ of mannitol. Influence of gentle rinsing (to remove unattached bacterial cells) versus vortexing (to remove unattached and weakly attached bacterial cells) on attachment levels was investigated. Attachment levels at harvest time are presented as the proportion of attached cells compared with the total number of inoculated cells (as percentage). Attachment levels below the detection limit are indicated $(*)$. Bars represent the standard error $(n=3)$. 
showed that glucose did not have the positive effect on attachment that was observed for mannitol, confirming the role of EPS production in irreversible root attachment.

Two types of experiments were conducted to evaluate whether the attachment levels could be overestimated as a consequence of bacterial growth during the course $(32 \mathrm{~h})$ of the experiment. First, total numbers of bacteria present inside the tubes containing the inoculated plants and the nutrient solution were determined and compared with the number of inoculated bacteria. The results indicated that, in the presence of mannitol, the total number of bacteria in each tube increased approximately $6 \%$ after $32 \mathrm{~h}$. When mannitol was absent, this percentage was even lower. Second, to exclude the possibility that substantial bacterial growth occurred specifically at the root surface, growth of attached bacteria was followed during $32 \mathrm{~h}$ after inoculation (Supplementary Fig. 4). Inoculated plants with attached PAL5 bacteria were gently rinsed (to remove unattached bacteria) and transferred to tubes containing sterile mannitol-free or mannitol-containing nutrient solution. Then, after different time intervals, plants were removed and bacteria attached to the roots were quantified. The bacterial numbers were compared with the number of attached cells at the time when the plants were transferred to fresh nutrient solution. The increase in cell numbers was considered to represent root surface-associated bacterial growth. This experiment indicated that, after $32 \mathrm{~h}$ of incubation, bacterial growth represented approximately $4.8 \%$ increase in cellular numbers associated with the root surface in the absence of mannitol whereas, in the presence of mannitol, there was an increase of $12 \%$. These growth numbers are small in comparison with the several-fold increases observed in the attachment experiments (Figs. 4 and 5), thus excluding a major implication of bacterial growth in the quantification of bacterial numbers.

\section{Addition of purified EPS partially restores attachment of the mutant MGD to rice roots.}

Because the mutant MGD was unable to attach to rice roots, regardless of the absence or presence of mannitol, we won-

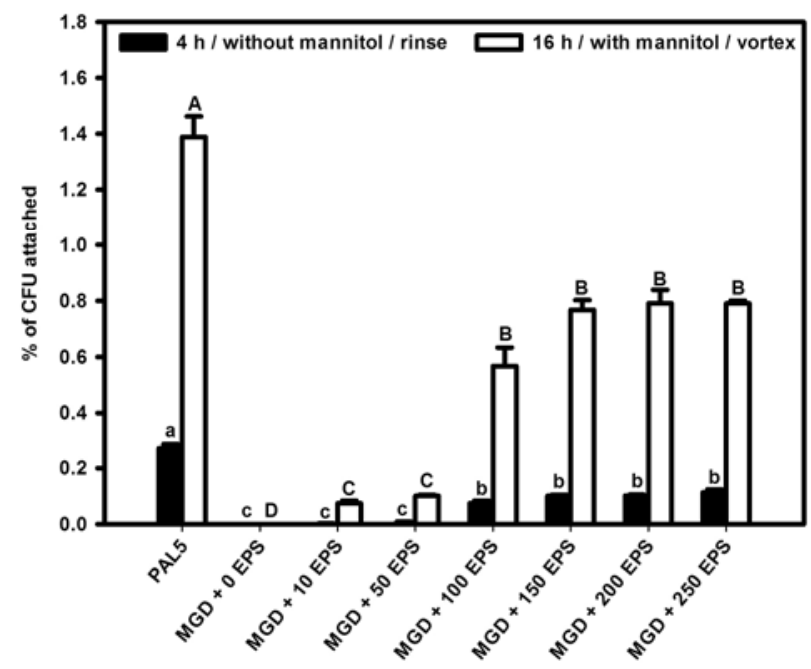

Fig. 6. Restoration of rice root surface attachment by MGD after addition of purified PAL5 exopolysaccharide (EPS). Weak ( $4 \mathrm{~h}$ of incubation, without mannitol, rinse) and irreversible (16 h of incubation, with mannitol, vortex) attachment by MGD cells was studied after the addition of different concentrations of purified PAL5 EPS. Final EPS concentrations are represented by numbers $(\mu \mathrm{g} / \mathrm{ml})$ below the $\mathrm{x}$-axis. Attachment levels at harvest time are presented as the proportion of attached cells compared with the total number of inoculated cells (as percentage). Bars represent the standard error $(n=3)$. Different letters indicate statistical difference (Tukey's test, $P<0.05$ ). dered if the addition of purified EPS could complement the attachment-deficient phenotype of MGD. The addition of purified EPS partially restored both the weak initial attachment and the irreversible attachment capabilities of MGD to the roots (Fig. 6). Similarly to what was observed for biofilm formation on glass wool, wild-type attachment levels were not attained and maximum attachment occurred after the addition of EPS at $150 \mu \mathrm{g} / \mathrm{ml}$ (Fig. 6). Additional increases in the amount of EPS did not further increase the attachment of the mutant to the rice roots. Also, in this experiment, the addition of mannitol led to an increase in the attachment levels.

\section{Visualization of surface colonization using $\boldsymbol{g} f \boldsymbol{p}$-marked $\boldsymbol{G}$. diazotrophicus strains.}

Rice root surface colonization was also studied by fluorescence microscopy using green fluorescent protein $(g f p)$-marked strains. At 10 days after inoculation (DAI), green fluorescent PAL5 (Fig. 7A) and CMGD (Fig. 7C) colonized the root surface, predominantly as bacterial aggregates at sites of secondary root emergence and on root hairs. In contrast, no fluorescent bacteria were visualized on the surface of seedlings inoculated with $g f p$-marked MGD (Fig. 7B), thus corroborating the results of quantification of bacterial attachment described above. In order to confirm the role of EPS, surface attachment was microscopically evaluated after addition of EPS at 100 $\mu \mathrm{g} / \mathrm{ml}$ at 4 and $16 \mathrm{~h}$ after inoculation. The addition of purified EPS to plants inoculated with PAL5 appeared to increase the levels of root attachment by PAL5 at both $4 \mathrm{~h}$ and $16 \mathrm{~h}$ (Fig. 7 $\mathrm{D}$ and $\mathrm{G}$, respectively) after inoculation, and CMGD presented a similar behavior (Figs. 7F and I). The addition of purified EPS to seedlings inoculated with $g f p$-marked MGD led to the formation of microaggregates of fluorescent MGD cells on the root surface at 4 and $16 \mathrm{~h}$ (Fig. 7E and $\mathrm{H}$, respectively) after inoculation. Because the bacterial counting experiments suggested the absence of substantial growth (multiplication) of $G$. diazotrophicus cells attached to the roots, presumably the microaggregates formed by MGD in the presence of purified EPS were due to the attachment of multiple bacterial cells rather than to root-surface-associated bacterial divisions. These data confirm the results obtained for the bacterial counting, demonstrating a role of EPS in bacterial attachment to rice root surface.

\section{The gumD gene and EPS have a role in endophytic colonization.}

The capacity of the mutant MGD to endophytically colonize rice seedlings was investigated. Confirming earlier findings (Rouws et al. 2010), which showed the presence of approximately $10^{8}$ and $10^{4} \mathrm{CFU} / \mathrm{g}$ of fresh mass for surface-associated and endophytic bacteria, respectively, PAL5 cells could be isolated from surface-sterilized rice roots and shoots at $10 \mathrm{DAI}$ (Figs. 8A and B). In contrast, no endophytic colonization was observed for the mutant MGD (Figs. 8A and B). Similar to what was observed in the root-surface attachment experiments, the addition of purified EPS to the plants at the time of inoculation partially restored the endophytic colonization by MGD in a dose-dependent manner. In contrast to the root-surface attachment experiments, endophytic colonization by PAL5 and CMGD was not increased by the addition of purified EPS (Figs. 8A and B). These data show that the gumD gene and the production of EPS are involved in endophytic colonization of rice seedlings by G. diazotrophicus.

\section{DISCUSSION}

Attachment of beneficial bacteria to the plant root surface is believed to be required to enable the subsequent endophytic 

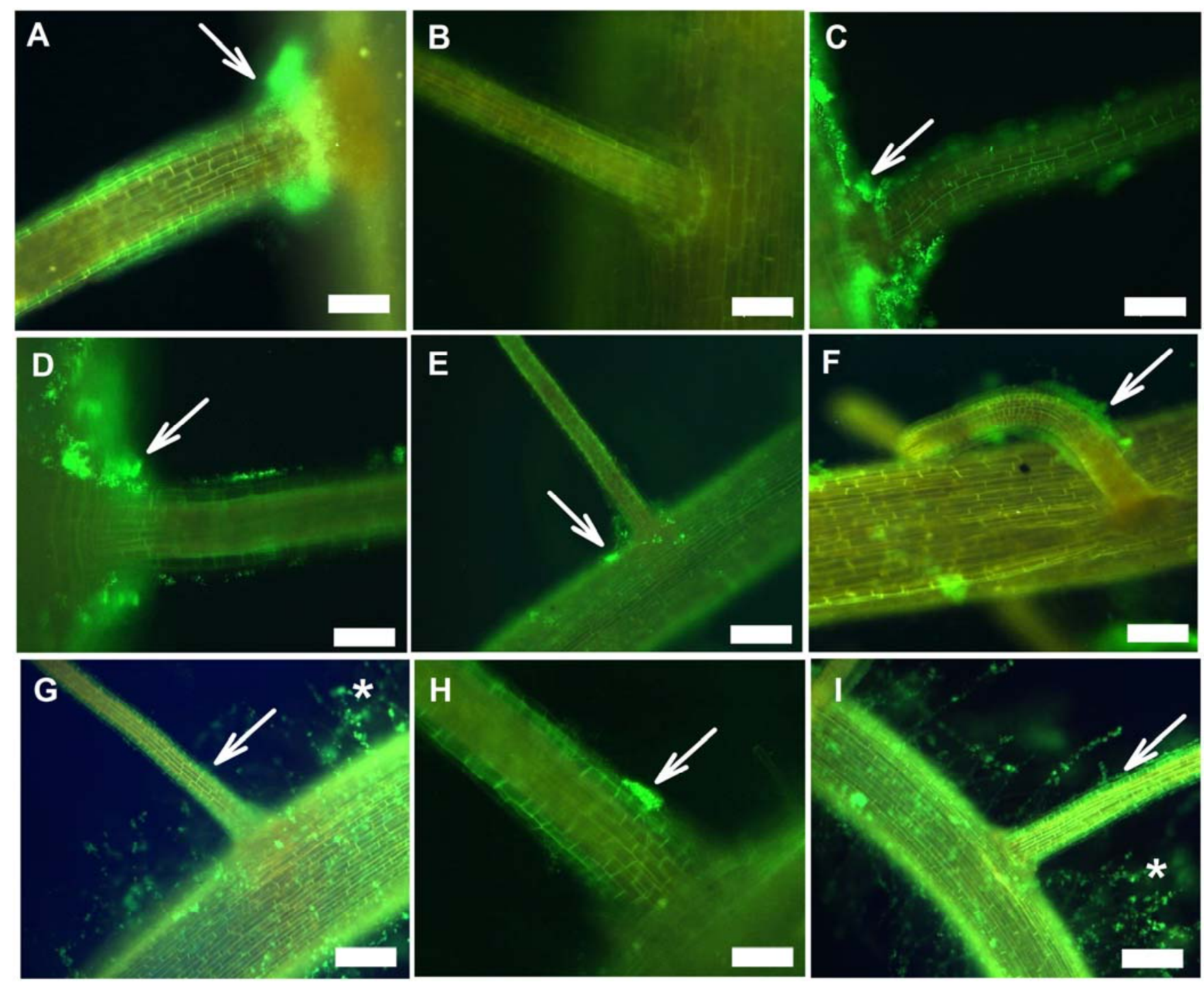

Fig. 7. Fluorescence microscopy of rice root surface colonization by green fluorescent protein ( $g f p$ )-marked Gluconacetobacter diazotrophicus strains. At 10 days after inoculation, $g f p$-marked A, PAL5 and C, CMGD cells were visualized on inoculated rice seedlings, predominantly at sites of secondary root emergence. B, Fluorescent bacteria were not seen on plants inoculated with MGD. When exopolysaccharide (EPS) (100 $\mu \mathrm{g} / \mathrm{ml}) \mathrm{was}$ added at $4 \mathrm{~h}$ after inoculation, D, PAL5 and F, CMGD could be seen attached to the root surface. E, Fluorescent MGD cells were also observed forming microaggregates on the root surface, although in lower quantities. After $16 \mathrm{~h}$ in the presence of EPS $(100 \mu \mathrm{g} / \mathrm{ml}), \mathbf{G}$, PAL5 and I, CMGD intensely colonized the root surface, forming large aggregates with an apparently loose structure $(*)$ that were concentrated on root hair zones. $\mathbf{H}$, Under these circumstances, MGD was seen forming microaggregates. Arrows indicate fluorescent bacteria. Scale bars represent $20 \mu \mathrm{m}(\mathrm{A}, \mathrm{B}, \mathrm{C}, \mathrm{D}, \mathrm{F}$, and H) or $50 \mu \mathrm{m}$ (E, G, and I).
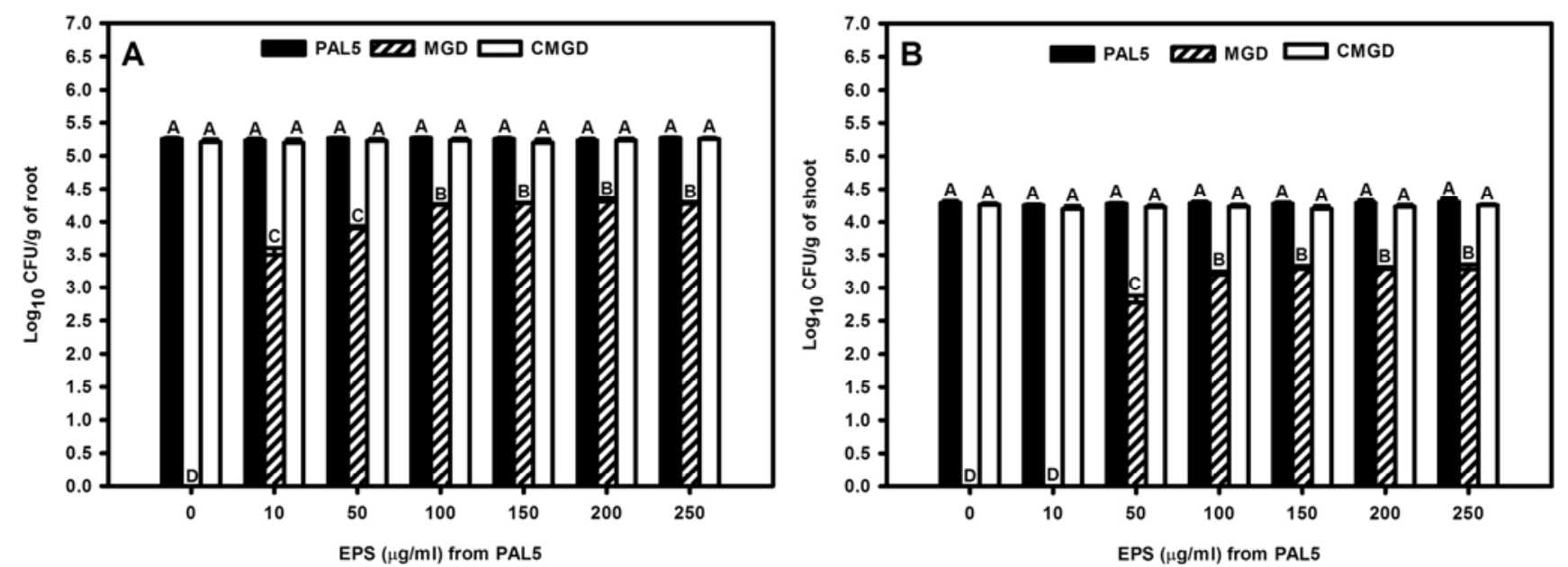

Fig. 8. Requirement of exopolysaccharide (EPS) for endophytic colonization of rice seedlings by Gluconacetobacter diazotrophicus. Endophytic colonization of $\mathbf{A}$, roots and $\mathbf{B}$, shoots of rice seedlings by PAL5, MGD, and CMGD was investigated at 10 days after inoculation in the presence or absence of the indicated concentrations of purified PAL5 EPS. Bars represent the standard error $(n=3)$. Different letters indicate statistical difference (Tukey's test, $P<0.05)$. 
colonization. On the other hand, attachment to the root surface alone is not sufficient for successful endophytic colonization, since Oliveira Pinheiro and associates (2002) showed that both exclusively rhizosphere-inhabiting and endophytic $A$. brasilense strains had similar root-attachment capabilities. During root colonization, after an initial weak binding phase, the bacteria form multicellular aggregates or biofilms in which the bacteria are embedded in a self-produced matrix composed of proteins, nucleic acids and EPS (Danhorn and Fuqua 2007; RodriguezNavarro et al. 2007). However, the role of EPS in root attachment and plant colonization by endophytic nitrogen-fixing bacteria such as $G$. diazotrophicus has not been reported on.

In the present study, the gum gene cluster from PAL5, which was hypothesized to be responsible for EPS production, was studied by bioinformatics techniques and by laboratory experiments. In general terms, the gum cluster of PAL5 was most similar to the ace EPS gene cluster from the phylogenetically closely related G. xylinus. However, four genes (gumE, gumJ, gumK, and eglA) were similar to genes from phylogenetically distant plant-associated bacteria Azoarcus sp. strain BH72 (endophyte) and phytopathogens from the genus Xanthomonas, which may be indicative of horizontal gene transfer.

Using a mutagenesis approach, we demonstrated that the gumD gene of $G$. diazotrophicus PAL5 is involved in EPS production. After genetic complementation, generating strain CMGD, EPS production was restored to wild-type levels. The complementation strategy applied here, in which the wild-type gumD gene was reintroduced into the chromosome by homologous recombination, does not completely eliminate the possibility of polar effects of the Tn5 insertion on genes downstream to gumD in MGD. Nevertheless, eventual polar effect would only affect nearby genes (gumM, gumC, gumH, ace $G$, and gumB) that are all predicted to be involved in the same process of EPS production, in which gumD catalyzes the first step (Fig. 1).

Depending on the carbon source, the quantity of carbohydrate in MGD culture supernatant that could be precipitated with ethanol was abolished (for glucose) or greatly reduced (for fructose, mannitol, and sucrose). The residual precipitates observed for these latter carbon sources might be explained in two ways. First, the solubility of sugars like sucrose and mannitol has been shown to decrease in the presence of ethanol; therefore, the precipitated carbohydrate may actually represent nonmetabolized sugar molecules (Bouchard et al. 2007; Quesada et al. 1993). This is in accordance with the sugar-like crystals that formed during the carbohydrate precipitation of MGD supernatant when sucrose was the carbon source. An explanation for the presence of residual polysaccharides in MGD supernatant may be the action of the G. diazotrophicus levansucrase (Hernández et al. 1995; Tapia-Hernández et al. 2000). This protein is responsible for the production of a levan-like fructan polymer in the extracellular milieu of $G$. $d i$ azotrophicus cells, using sucrose as a precursor molecule.

A series of experiments involving the MGD mutant indicated that the functional gumD gene is involved in biofilm formation on glass wool, rice root surface colonization, and endophytic colonization of rice seedlings. Addition of purified PAL5 EPS partially restored the deficiencies presented by the MGD mutant, providing further evidence that the observed mutant phenotypes were due to a deficiency in EPS production.

The restoration of EPS nonproducing phenotypes has been also demonstrated for phytopathogenic bacteria such as $X$. campestris (Yun et al. 2006) and rhizobia such as Bradyrhizobium japonicum USDA 110 (Quelas et al. 2010), Rhizobium leguminosarum bv. trifolii (Djordjevic et al. 1987), and Sinorhizobium (Ensifer) meliloti (Urzainqui and Walker 1992).

The important role of bacterial EPS as a principal matrix component in biofilms is well established. However, in some cases, biofilm formation is not completely abolished in EPS nonproducing mutants (Fujishige et al. 2006) whereas, in others, mutants unable to synthesize the EPS do not form biofilms at all (Watnick and Kolter 1999; this study). It should be mentioned that an intrinsic problem of the biofilm assay used in this study, and of several other biofilm assays, is that these do not allow observers to distinguish among the phases of biofilm formation, which include initial surface attachment and subsequent development and maturation (O'Toole and Kolter 1998).

The interaction between wheat and the diazotrophic bacterium $A$. brasilense suggested that the initial weak attachment of the bacteria to the root involves flagella but not EPS and that the subsequent irreversible attachment phase depends on EPS biosynthesis (Croes et al. 1993; Michiels et al. 1991). Similar results were also obtained for colonization of rice roots by Alcaligenes faecalis, when an EPS nonproducing mutant showed normal weak attachment levels but displayed reduced irreversible attachment (You et al. 1995). In contrast, data presented here show that, apart from the irreversible attachment, EPS of G. diazotrophicus PAL5 is also required for the initial weak attachment phase to the rice root. The inoculated cells were washed with saline, thus removing much of EPS already present in the bacterial culture. Because it seems unlikely that PAL5 would be able to synthesize EPS in only $15 \mathrm{~min}$, it can be speculated that some of the EPS is intimately bound to the cell surface, preventing it from being removed by washing in saline. Also, it was observed that, $16 \mathrm{~h}$ after inoculation, PAL5 cells were able to firmly attach to rice roots, even when no carbon source (mannitol) was supplied. Under these circumstances, rice root exudates, which are known to contain substantial quantities of carbohydrates, may have provided carbohydrates for EPS production (Bacilio-Jiménez et al. 2003). Nevertheless, the addition of mannitol strongly enhanced the irreversible attachment phase.

Although the mutant MGD was unable to endophytically colonize rice seedlings, this deficiency could be partially overcome by adding purified EPS. Two hypotheses might explain this effect: i) the addition of purified EPS may enable the attachment to the root surface, after which the endophytic colonization occurs independently of EPS, or ii) apart from surface binding and colonization, EPS may be also required during plant penetration and endophytic establishment. The present data do not allow us to distinguish between these two possibilities. For wheat plants, cracks formed at sites of lateral root emergence and between epidermal cells were shown to be preferential sites for colonization by Azospirillum strains (Oliveira Pinheiro et al. 2002). Microscopy data have shown that $G$. diazotrophicus has a preference for similar sites on the roots of rice; therefore, it seems most probable that $G$. diazotrophicus colonizes the host plant through cracks (James and Olivares 1998; Rouws et al. 2010; this study). The endoglucanase gene eglA present on the PAL5 genome might have an auxiliary function in the endophytic colonization process (Bertalan et al. 2009). The importance of EPS production during plant colonization has been previously suggested in several microscopic studies with sugarcane. In these studies, xylem-colonizing $G$. diazotrophicus were seen to be surrounded by electron transparent "haloes", suggested to be composed of EPS (James et al. 1994, 2001). This observation would suggest that EPS also has a role in the establishment and survival of the bacteria inside the plant once they have penetrated the internal tissues.

Capsules of EPS surrounding bacteria have been believed to shield microbe-associated molecular patterns from being detected by the plant defense systems (Denny 1995; Milling et al. 2011). However, a recent study showed that Ralstonia solanacearum EPS may also form a direct signal toward the plant, inducing a defense response (Milling et al. 2011). Sev- 
eral studies with sugarcane have shown that $G$. diazotrophicus and other endophytes differentially influence sugarcane gene expression when compared with pathogenic bacteria (Cavalcante et al. 2007; Vinagre et al. 2006). Therefore, in future studies, it would be of interest to investigate whether the $G$. diazotrophicus EPS, apart from having a structural function, also has a role in signaling. To our knowledge, this is the first report of a determinant role of EPS produced by a diazotrophic bacterium in the endophytic colonization of a graminaceous host plant.

\section{MATERIALS AND METHODS}

\section{Annotation of the putative EPS biosynthetic cluster.}

The genes from the PAL5 gum cluster mentioned in this study are available in GenBank as follows: gumJ (YP_001602779), GDI_2536 (YP_001602780), eglA (YP_001602781), gumE (YP_001602782), GDI_2539 (YP_001602783), gumK (YP_ 001602786), GDI_2543 (YP_001602787), GDI_2544 (YP_ 001602788), ugd (YP_001602789), gumD (YP_001602791), gumM (YP_001602792), GDI_2549 (YP_001602793), gumH (YP_001602794), GDI_2551 (YP_001602795), and gumB (YP_001602796). Comparative (ortholog detection) and functional analyses of the gum cluster of G. diazotrophicus PAL5 genome were done using BLAST (Altschul et al. 1990). The KEGG system (Kanehisa and Goto 2000), Gene Context 2 (Martinez-Guerrero et al. 2008), Pfam (Bateman et al. 2002), and the enzyme nomenclature bank (Expasy Enzyme) (Gasteiger et al. 2003) were used to confirm the results.

\section{Strain, culture media, and growth conditions used.}

G. diazotrophicus PAL5 (BR 11281, ATCC49037) was obtained from the Embrapa Agrobiologia Culture Collection and grown in Dygs liquid medium (Rodrigues Neto et al. 1986). Antibiotics kanamycin $(200 \mu \mathrm{g} / \mathrm{ml})$ or ampicillin $(500 \mu \mathrm{g} / \mathrm{ml})$ were added when required. G. diazotrophicus PAL5 electrocompetent cells were prepared using liquid C2 medium as described previously (Rouws et al. 2008). For cloning purposes, E. coli DH10B cells were cultivated in Luria-Bertani (LB) medium (Sambrook et al. 1989), amended with the selective antibiotics kanamycin $(50 \mu \mathrm{g} / \mathrm{ml})$ or ampicillin $(100 \mu \mathrm{g} / \mathrm{ml})$.

\section{Cloning and mutagenesis of G. diazotrophicus PAL5 gumD (pGEMGD).}

The PAL5 gumD homologue was amplified by PCR with primers gumD-sense (5'-ACAAGCTTCGCTTGCCCGATGG AGATC-3') and gumD-antisense (5'-CAGAATTCGCGTCAG AAGGCATGACGGC-3') using Taq polymerase (Invitrogen, Paisley, U.K.). The 1,521-bp PCR product was cloned into the pGEM-T easy vector (Promega Corp., Madison, WI, U.S.A.). After confirming the success of the cloning procedure by restriction analysis and sequencing, one recombinant plasmid containing the desired fragment was selected and designated pGEMGD. The plasmid pGEMGD was mutagenized in vitro by the insertion of the commercial EZ::Tn5<KAN2>Transposon (Tn5) (Epicentre Technologies Corp., Madison, WI, U.S.A.) following the instructions of the manufacturer. The mutagenized plasmid was transferred to E. coli $\mathrm{DH} 10 \mathrm{~B}$ and plated on LB medium containing ampicillin and kanamycin to select plasmids containing insertions of the transposon in the target gene. Restriction analysis and sequencing led to the identification of the plasmid pMUTGD with a single insertion of the transposon in the gumD gene, located 410 bp downstream the predicted ATG start codon. PAL5 was transformed with $1 \mu \mathrm{g}$ of the plasmid pMUTGD by electroporation as described (Rouws et al. 2008), and selection on Dygs plate medium amended with kanamycin allowed the selection of two transformants containing Tn5 integrations in their genomes. A second round of selection on Dygs plate medium containing both kanamycin and ampicillin permitted the selection of one mutant resistant only to kanamycin. This indicated that the backbone of the mutagenic plasmid had been eliminated by the mechanism of double crossing-over, leaving only an insertion of the transposon at the desired site. The insertion of the transposon in the $G$. diazotrophicus genome was verified by applying IPCR followed by sequencing of the product as previously described (Rouws et al. 2008).

\section{Genetic complementation of mutant MGD.}

The wild-type gumD gene, including 664 bp upstream of the start codon, assumed to contain the transcription promoter, was amplified from the $G$. diazotrophicus PAL5 genome by PCR with Pfx polymerase (Invitrogen) and primers pgumD-F (5'-GCTGACCGAATGGAACGAAT-3') and pgumD-R (5'CGTTCACGATCAGCATCTTC-3'). The PCR product was modified by the A-tailing procedure (pGEM-T easy manual; Promega Corp.) and cloned into pGEM-T easy vector, giving rise to the plasmid pGUMD. After verifying this construct by restriction analysis and sequencing, it was introduced into mutant MGD by electroporation. Selection on Dygs plates containing both kanamycin and ampicillin permitted the selection of a strain containing the pGUMD plasmid integrated into the chromosome. Southern blot analysis with EcoRI-digested genomic DNA confirmed that the wild-type gumD locus was restored in this strain, which was designated CMGD.

\section{Morphological and physiological studies.}

Growth of wild-type and G. diazotrophicus mutant in liquid cultures was followed by measuring the optical density at 600 $\mathrm{nm}\left(\mathrm{OD}_{600}\right)$ and counting of bacterial numbers. Strains were grown in 250-ml flasks containing $50 \mathrm{ml}$ of liquid Dygs medium $\left(200 \mathrm{rpm}, 30^{\circ} \mathrm{C}\right)$ and, every $6 \mathrm{~h}, 1-\mathrm{ml}$ samples were removed for analysis. For counting, samples were serially diluted in saline $(\mathrm{NaCl} 0.7 \%$ [wt/vol] solution) and 10- $\mu$ l droplets of each dilution were deposited onto LGI-P medium (Reis et al. 1994) amended with yeast extract as a nitrogen source. After incubation for 3 days at $30^{\circ} \mathrm{C}$, colonies were counted and CFU were determined. Pellicle formation was evaluated by growing the indicated strains in $\mathrm{N}$-free semisolid LGI-P medium. $\mathrm{N}$ fixation activity of these cultures was determined using the acetylene reduction technique with a Perkin Elmer Auto System II gas chromatograph (Perkin Elmer, Japan, Yokohama, Japan).

\section{EPS purification and quantification.}

The production of EPS by G. diazotrophicus wild-type and mutant strains was evaluated after growing on different carbon sources (glucose, sucrose, fructose, and mannitol; $20 \mathrm{~g} / \mathrm{liter}$ each). The cells were grown for $72 \mathrm{~h}$ in an orbital shaker (200 $\mathrm{rpm}, 30^{\circ} \mathrm{C}$ ) in $250-\mathrm{ml}$ flasks containing $50 \mathrm{ml}$ of LGI medium (Cavalcante and Döbereiner 1988) modified by substituting for the respective carbon sources. Cell growth was accompanied by measuring the $\mathrm{OD}_{600}$, and the EPS present in culture supernatants were precipitated with ethanol. The precipitated EPS was then dissolved in MilliQ $\mathrm{H}_{2} \mathrm{O}$ (Quesada et al. 1993). Quantities of EPS were determined by quantifying total carbohydrates using the colorimetric phenol sulfuric method as described (Dubois et al. 1956). The resultant OD values were then compared with a calibration curve that was generated using different glucose concentrations $(0,20,40,60,80,100$, and $200 \mu \mathrm{g} / \mathrm{ml})$.

\section{Colony morphology and flagellar motility.}

Colony morphology of wild-type and mutant G. diazotrophicus strains was evaluated on modified LGI medium containing $0.3,0.7$, and $1.5 \%$ agar. Cell samples $(10 \mu \mathrm{l})$ resus- 
pended in saline solution were inoculated onto the center of the solid culture media in 12-well tissue culture plates. The colony morphology was evaluated after growth for $72 \mathrm{~h}$ at $30^{\circ} \mathrm{C}$ using a stereoscopic microscope.

\section{Biofilm formation and quantification.}

Biofilm formation was evaluated essentially as described (Rouws et al. 2008) with few modifications. Briefly, $1.0 \times 10^{6}$ CFU in saline solution were inoculated into 125 -ml flasks containing $25 \mathrm{ml}$ of modified LGI medium and $0.1 \mathrm{~g}$ of glass wool (Merck, Darmstadt, Germany). Glucose or mannitol (5 g/liter) were used as the carbon source as indicated. Where indicated, purified EPS was added at the respective final concentrations $(10,50,100,150,200$, and $250 \mu \mathrm{g} / \mathrm{ml})$.

After $72 \mathrm{~h}$ of growth, the glass wool was washed for $5 \mathrm{~min}$ with phosphate buffer ( $50 \mathrm{mM}, \mathrm{pH} 7.2)$ and then stained for 10 min with $1 \%$ crystal violet solution (wt/vol). For quantification, the glass wool was washed four times (15 min each) with phosphate buffer $(50 \mathrm{mM}, \mathrm{pH} 7.2)$ and extracted two times with $1 \mathrm{ml}$ of absolute ethanol. After pooling the two extracts, the $\mathrm{OD}_{560}$ was determined by spectrophotometry.

\section{Hydroponic rice cultures.}

Rice seedlings were cultivated basically as described (Rouws et al. 2010). Briefly, seed of 'IAC-4440' rice were peeled, surface sterilized, and germinated in the dark on $1 \%$ agar containing yeast extract at $500 \mathrm{mg} / \mathrm{liter}$. After 3 days, seedlings free of visible contamination were transplanted to glass tubes $(250$ by $35 \mathrm{~mm}$ ) containing $30 \mathrm{ml}$ of Hoagland's solution (Arnon and Hoagland 1940) free of nitrogen. After 7 days in a growth chamber at $28^{\circ} \mathrm{C}$, with a 12 -h photoperiod with light provided by fluorescent tubes, the seedlings were used in experimental procedures as described below for the respective experiments.

\section{Surface-attachment experiments.}

Surface-attachment experiments were done using an adaptation of the methodology described by Michiels and associates (1991). A major difference was that, in the present study, bacterial root attachment was evaluated by CFU counting and not by the radioactive labeling and scintillation counting used by Michiels and associates (1991). Bacterial inoculants were cultivated overnight in Dygs (for G. diazotrophicus) or LB (E. coli DH10B) liquid media, washed twice in saline, and suspended in one volume of saline. Glass tubes ( 150 by $15 \mathrm{~mm}$ ) containing $5 \mathrm{ml}$ of $\mathrm{N}$-free Hoagland's solution without or with $0.5 \%$ (wt/vol) mannitol (to maximize EPS production) were inoculated with $1.1 \times 10^{9}$ washed viable cells of the indicated bacterial strains. Where indicated, purified EPS (10, 50, 100, 150,200 , and $250 \mu \mathrm{g} / \mathrm{ml}$ final concentration) was added at this point.

A single rice seedling, grown in hydroponic culture as described above, was introduced into each tube with its root system completely immersed in the solution. The tubes were incubated in a vertical position on a rotary shaker at $30^{\circ} \mathrm{C}$ and 100 rpm. At different times after inoculation (15 and $30 \mathrm{~min}$ and 1, $2,4,16$, and $32 \mathrm{~h}$ ), the plants were removed from the tubes. The roots of each plant were then rinsed by consecutive immersions in three $50-\mathrm{ml}$ portions of sterile water for $1 \mathrm{~min}$ each (to study the initial weak attachment phase), or submitted to vortexing for $5 \mathrm{~s}$ in $25 \mathrm{ml}$ of sterile water (repeated three times changing water each time) in the case of irreversible attachment measurements.

Then, the roots were separated from the aerial parts by cutting them just below the seed and macerated in a mortar in the presence of $500 \mu \mathrm{l}$ of saline. The resultant suspension was serially diluted and plated on LGI-P plates amended with yeast extract at $50 \mathrm{mg} / \mathrm{liter}$. Colonies were counted after 3 days of incubation at $30^{\circ} \mathrm{C}$. For the $E$. coli control, the dilutions were deposited on LB plates.

In order to investigate eventual endophytic colonization during the incubation period of these surface-attachment experiments, some inoculated plants were incubated for $32 \mathrm{~h}$ in the presence of mannitol, as described above, and then surface disinfested with chloramine-T $1 \%$ (wt/vol) for $2 \mathrm{~min}$. Then, the roots were processed as described and the presence of inoculated bacteria inside the roots was evaluated.

Two types of experiments were conducted to investigate the occurrence of substantial undesired bacterial growth throughout the attachment experiments. For the first approach, after different time intervals (up to $32 \mathrm{~h}$ after inoculation), the whole content of glass tubes (including the $5 \mathrm{ml}$ of Hoagland's solution inoculated with $1 \times 10^{9} \mathrm{CFU}$ of PAL5 cells and the seedling) was pooled and homogenized. CFU present in the resultant suspension were then quantified by serial dilution and plating. Resultant bacterial numbers were compared with the number of inoculated bacteria $\left(1 \times 10^{9}\right)$, allowing us to estimate the bacterial growth that occurred during the experiment. Experiments were conducted in triplicate.

For the second approach, seedlings in glass tubes containing $5 \mathrm{ml}$ of Hoagland's solution with or without mannitol were inoculated with $1 \times 10^{9} \mathrm{CFU}$ of PAL5 cells. After $1 \mathrm{~h}$, the seedlings were removed, rinsed three times for $1 \mathrm{~min}$ in $50 \mathrm{ml}$ of sterile water to remove unattached bacteria, and transferred (with attached bacteria) to new tubes containing $5 \mathrm{ml}$ of Hoagland's solution with or without mannitol (in accordance with the previous incubation step). After 15 and $30 \mathrm{~min}$ and 1 , $2,4,16$, and $32 \mathrm{~h}$, seedlings were removed and the roots were removed and macerated in saline. After serially diluting, plating, and CFU counting, the attached bacteria could be quantified. Increases of attached bacteria during the course of the experiment were assumed to be due to bacterial growth. Experiments were conducted in triplicate.

\section{Fluorescent microscopy using GFP-marked strains.}

G. diazotrophicus strains PAL5, MGD, and CMGD were transformed with the $g f p$ plasmid pHRGFPTC by electroporation as described (Ramos et al. 2002; Rouws et al. 2010). Approximately $3 \times 10^{6} \mathrm{CFU}$ of the GFP-labeled strains grown in liquid Dygs medium, harvested, and suspended in $10 \mu \mathrm{l}$ saline were added directly into the Hoagland's solution of 7-day-old hydroponically grown rice seedlings. Control plants were inoculated with $10 \mu \mathrm{l}$ of saline solution. Where indicated, purified EPS $(100 \mu \mathrm{g} / \mathrm{ml})$ was also added. The plants were then incubated for 4 or $16 \mathrm{~h}$ on a rotary shaker at $30^{\circ} \mathrm{C}$ and $100 \mathrm{rpm}$ in vertical position or grown for 10 days under a 12-h photoperiod as described above.

Fresh root tissues were then collected for microscopy analysis. Samples were incubated for $2 \mathrm{~h}$ at $4^{\circ} \mathrm{C}$, sliced, and visualized under a Zeiss Axioplan microscope (Carl Zeiss, Jena, Germany). Images were captured with a Carl Zeiss AxioCam 6.08.0 digital camera (Carl Zeiss) using 450- to 490-nm (excitation) and 520-nm (suppressor) filters.

\section{Endophytic colonization experiments.}

Endophytic colonization was evaluated as previously described (Rouws et al. 2010). Briefly, $3 \times 10^{6} \mathrm{CFU}$ of the $G$. diazotrophicus strains suspended in $10 \mu \mathrm{l}$ of saline were added directly into the Hoagland's solution $(30 \mathrm{ml})$ of 7-day-old rice seedlings that were grown as described above. Control plants were inoculated with $10 \mu \mathrm{l}$ of saline solution. At $10 \mathrm{DAI}$, the roots were separated from the aerial parts and weighed after draining the adhering liquid on absorbent paper. The root surface was disinfected by incubation in a freshly prepared 
chloramine $\mathrm{T}$ solution (1\% [wt/vol]) for $2 \mathrm{~min}$ under gentle agitation. After extensive washing with sterile water, the intact roots were placed on LGI-P plates for $10 \mathrm{~s}$ to verify the surface sterilization procedure. For each plant, a stem piece of approximately $5 \mathrm{~cm}$ in length had its outer leaf sheet aseptically removed and was weighed, briefly immersed in $70 \%$ ethanol, and left to dry for $1 \mathrm{~min}$. The surface-disinfected root and shoot materials were ground in a mortar and CFU were quantified. Bacteria (CFU) present in the Hoagland's solution at harvest time were also quantified and served as a control to evaluate bacterial growth during the incubation period.

\section{ACKNOWLEDGMENTS}

This work was supported by the projects Pronex (FAPERJ/CNPq), $\mathrm{MCT} / \mathrm{CNPq} / \mathrm{Etanol}$, INCT-FBN, and Embrapa (MP2-Genoprot). We thank E. K. James and F. L. Olivares for helping with the light microscopy analysis; and S. Schwab, S. M. Campbell Alquéres, and R. M. Boddey for critically reading the manuscript. C. H. S. G. Meneses and J. I. Baldani thank CAPES and CNPq for the fellowships.

\section{LITERATURE CITED}

Altschul, S. F., Gish, W., Miller, W., Myers, E. W., and Lipman, D. J. 1990. Basic local alignment search tool. J. Mol. Biol. 215:403-410.

Arnon, D. I., and Hoagland, D. R. 1940. Crop production in artificial culture solutions and in soils with special reference to factors influencing yields and absorption of inorganic nutrients. Soil Sci. 50:463-483.

Assmus, B., Hutzler, P., Kirchhof, G., Amann, R., Lawrence, J. R., and Hartmann, A. 1995. In situ localization of Azospirillum brasilense in the rhizosphere of wheat with fluorescently labeled, rRNA-targeted oligonucleotide probes and scanning confocal laser microscopy. Appl. Environ. Microbiol. 61:1013-1019.

Bacilio-Jiménez, M., Aguilar-Flores, S., Ventura-Zapata, E., Pérez-Campos, E., Bouquelet, S., and Zenteno, E. 2003. Chemical characterization of root exudates from rice (Oryza sativa) and their effects on the chemotactic response of endophytic bacteria. Plant Soil 249:271-277.

Baldani, J. I., and Baldani, V. L. D. 2005. History on the biological nitrogen fixation research in graminaceous plants: Special emphasis on the Brazilian experience. An. Acad. Bras. Cienc. 77:549-579.

Baldani, J. I., Caruso, L., Baldani, V. L. D., Goi, S. R., and Döbereiner, J. 1997. Recent advances in BNF with non-legume plants. Soil Biol. Biochem. 29:911-922.

Bateman, A., Birney, E., Cerrutti, L., Burbin, R., Etwiller, L., Eddy, S. R., Griffiths-Jones, S., Howe, K. L., Marshall, M., and Sonnhammer, E. L. 2002. The Pfam protein families database. Nucleic Acids Res. 30:276280.

Bertalan, M., Albano, R., de Pádua, V., Rouws, L., Rojas, C., Hemerly, A., Teixeira, K., Schwab, S., Araujo, J., Oliveira, A., França, L., Magalhães, V., Alquéres, S., Cardoso, A., Almeida, W., Loureiro, M. M., Nogueira, E., Cidade, D., Oliveira, D., Simão, T., Macedo, J., Valadão, A., Dreschsel, M., Freitas, F., Vidal, M., Guedes, H., Rodrigues, E., Meneses, C., Brioso, P., Pozzer, L., Figueiredo, D., Montano, H., Junior, J., de Souza Filho, G., Martin Quintana Flores, V., Ferreira, B., Branco, A., Gonzalez, P., Guillobel, H., Lemos, M., Seibel, L., Macedo, J., AlvesFerreira, M., Sachetto-Martins, G., Coelho, A., Santos, E., Amaral, G., Neves, A., Pacheco, A.B., Carvalho, D., Lery, L., Bisch, P., Rössle, S.C., Urményi, T., Rael Pereira, A., Silva, R., Rondinelli, E., von Krüger, W., Martins, O., Baldani, J. I., and Ferreira, P. C. 2009. Complete genome sequence of the sugarcane nitrogen-fixing endophyte Gluconacetobacter diazotrophicus PAL5. BMC Genomics 10:1-17.

Bouchard, A., Hofland, G. W., and Witkamp, G. 2007. Properties of sugar polyol and polysaccharide water-ethanol solutions. J. Chem. Eng. Data 52:1838-1842.

Cavalcante, V. A., and Dobereiner, J. 1988. A new acid-tolerant nitrogenfixing bacterium associated with sugarcane. Plant Soil 108:23-31.

Cavalcante, J. J., Vargas C., and Nogueira E. M. 2007. Members of the ethylene signaling pathway are regulated in sugarcane during the association with nitrogen-fixing endophytic bacteria. J. Exp. Bot. 58:673686.

Chou, F. L., Chou, H. C., Lin, Y. S., Yang, B. Y., Lin, N. T., Weng, S. F., and Tseng, Y. H. 1997. The Xanthomonas campestris gumD gene required for synthesis of xanthan gum is involved in normal pigmentation and virulence in causing black rot. Biochem. Biophys. Res. Commun. 233:265-269.

Colquhoun, I. J., Defernez, M., and Morris, V. J. 1995. NMR studies of acetan and the related bacterial polysaccharide, CR1/4, produced by a mutant strain of Acetobacter xylinum, Carbohydr. Res. 269:319-331.

Compant, S., Clément, C., and Sessitsch, A. 2010. Plant growth-promoting bacteria in the rhizo- and endosphere of plants: Their role, colonization, mechanisms involved and prospects for utilization. Soil Biol. Biochem. 42:669-678.

Croes, C. L., Moens, S., Van Bastelaere, E., Vanderleyden, J., and Michiels, K. W. 1993. The polar flagellum mediates Azospirillum brasilense adsorption to wheat roots. J. Gen. Microbiol. 139:2261-2269.

Danhorn, T., and Fuqua, C. 2007. Biofilm formation by plant-associated bacteria. Annu. Rev. Microbiol. 61:401-422.

Denny, T. P. 1995. Involvement of bacterial polysaccharides in plant pathogenesis. Annu. Rev. Phytopathol. 33:173-197.

Djordjevic, M. A., Redmond, J. W., Batley, M., and Rolfe, B. G. 1987. Clover secrete specific phenolic compounds which either stimulate or repress nod gene expression in Rhizobium trifolii. EMBO (Eur. Mol. Biol. Organ.) J. 6:1173-1179.

Dow, J. M., Newman, A. A., and von Roepenack, E. 2000. The induction and modulation of plant defense responses by bacterial lipopolysaccharides. Annu. Rev. Phytopathol. 38:241-261.

Dubois, M., Gilles, K. A., Hamilton, J. K., Rebers, P. A., and Smith, F 1956. Colorimetric method for determination of sugars and related substances. Anal. Chem. 28:350-356.

Fitriyanto, N. A., Nakamura, M., Muto, S., Kato, K., Yabe, T., Iwama, T., Kawai, K., and Pertiwiningrum, A. 2011. Ce3+-induced exopolysaccharide production by Bradyrhizobium sp. MAFF211645. J. Biosci. Bioeng. 111:146-152.

Fujishige, N. A., Kapadia, N. N., De Hoff, P. L., and Hirsch, A. M. 2006 Investigations of Rhizobium biofilm formation. FEMS (Fed. Eur. Microbiol. Soc.) Microbiol. Ecol. 56:195-206.

Gasteiger, E., Gattiker, A., Hoogland, C., Ivanyi, I., Appel, R. D., and Bairoch, A. 2003. ExPASy: The proteomics server for in-depth protein knowledge and analysis. Nucleic Acid Res. 31:3784-3788.

Griffin, A. M., Morris, V. J., and Gasson, M. J. 1996. Identification, cloning and sequencing the aceA gene involved in acetan biosynthesis in Acetobacter xylinum. FEMS (Fed. Eur. Microbiol. Soc.) Microbiol. Lett. 137:115-121.

Hallack, L. F., Passos, D. S., Mattos, K. A., Agrellos, O. A., Jones, C., Mendonca-Previato, L., Previato, J. O., and Todeschini, A. R. 2010 Structural elucidation of the repeat unit in highly branched acidic exopolysaccharides produced by nitrogen fixing Burkholderia. Glycobiology 20:338-347.

Hartmann, A., Baldani, J. I., Kirchhof, G., Assmus, B., Hurzler, P., Springer, N., Ludwig, W., Baldani, V. L. D., and Dobereiner, J. 1995 Taxonomic and ecologic studies of diazotrophic rhizosphere bacteria using phylogenetic probes. Pages 415-427 in: Azospirillum VI and Related Microorganisms: Genetics, Physiology, Ecology. NATO ASI Series. Series G, Ecological Sciences 37. I. Fendrik, M. del Gallo, J. Vanderleyden, and M. de Zamaroczy, eds. Springer, Berlin.

Hernández, L., Arrieta, J., Menéndez, C., Vázquez, R., Coego, A., Suárez, V., Selman, G., Petit-Glatron, M. F., and Chambert, R. 1995. Isolation and enzymic properties of levansucrase secreted by Acetobacter diazotrophicus SRT4, a bacterium associated with sugar cane. Biochem. J. 309:113-118.

Hurek, T., and Reinhold-Hurek, B. 2003. Azoarcus sp. strain BH72 as a model for nitrogen-fixing grass endophytes. J. Biotechnol. 106:169178.

Ishida, T., Sugano, Y., and Shoda, M. 2002. Novel glycosyltransferase genes involved in the acetan biosynthesis of Acetobacter xylinum. Biochem. Biophys. Res. Commun. 295:230-235.

James, E. K., and Olivares, F. L. 1998. Infection and colonization of sugar cane and other graminaceous plants by endophytic diazotrophs. CRC Crit. Rev. Plant Sci. 17:77-119.

James, E. K., Reis, V. M., Olivares, F. L., Baldani, J. I., and Döbereiner, J. 1994. Infection of sugar cane by the nitrogen-fixing bacterium Acetobacter diazotrophicus. J. Exp. Bot. 45:757-766.

James, E. K., Olivares, F. L., Oliveira, A. L. M., Reis, F. B., Jr., Silva, L. G., and Reis, V. M. 2001. Further observations on the interaction between sugar cane and Gluconacetobacter diazotrophicus under laboratory and greenhouse conditions. J. Exp. Bot. 52:747-760.

Jansson, P. E., Kenne, L., and Lindberg, B. 1975. Structure of extracellular polysaccharide from Xanthomonas campestris. Carbohydr. Res. 45:275282.

Kanehisa, M., and Goto, S. 2000. KEGG: Kyoto Encyclopedia of Genes and Genomes. Nucleic Acids Res. 28:27-30.

Katzen, F., Becker, A. Zorreguieta, A., Puhler, A., and Ielpi, L. 1996. Promoter analysis of the Xanthomonas campestris pv. campestris gum operon directing biosynthesis of the xanthan polysaccharide. J. Bacteriol. 178:4313-4318.

Kemp, B. P., Horne, J., Bryant, A., and Cooper, R. M. 2004. Xanthomonas 
axonopodis pv. manihotis gumD gene is essential for EPS production and pathogenicity and enhances epiphytic survival on cassava (Manihot esculente). Physiol. Mol. Plant Pathol. 64:209-218.

Kim, S. Y., Kim, J. G., Lee, B. M., and Cho, J. Y. 2009. Mutational analysis of the gum gene cluster required for xanthan biosynthesis in Xanthomonas oryzae pv. oryzae. Biotechnol. Lett. 31:265-270.

Krause, A., Ramakumar, A., Bartels, D., Battistoni, F., Bekel, T., Boch, J., Böhm, M., Friedrich, F., Hurek, T., Krause, L., Linke, B., McHardy, A., Sarkar, A., Schneiker, S., Syed, A. A., Thauer, R., Vorhölter, F. Weidner, S., Pühler, A., Reinhold-Hurek, B., Kaiser, A., and Goesmann, A. 2006. Complete genome of the mutualistic, $\mathrm{N}_{2}$-fixing grass endophyte Azoarcus sp. strain BH72. Nat. Biotechnol. 24:385-391.

Martinez-Guerrero, C. E., Ciria, R., Abreu-Goodger, C., Moreno-Hagelsieb, G., and Merino, E. 2008. GeConT 2: Gene context analysis for orthologous proteins, conserved domains and metabolic pathways. Nucleic Acids Res. 36:176-180.

Michiels, K. W., Croes, C. L., and Vanderleyden, J. 1991. Two different modes of attachment of Azospirillum brasilense $\mathrm{Sp} 7$ to wheat roots. J. Gen. Microbiol. 137:2241-2246.

Milling, A., Babujee, L., and Allen, C. 2011. Ralstonia solanacearum extracellular polysaccharide is a specific elicitor of defense responses in wilt-resistant tomato plants. PLoS One 6:e15853.

Morris, J., and Gonzalez, J. E. 2009. The novel genes emmABC are associated with exopolysaccharide production, motility, stress adaptation, and symbiosis in Sinorhizobium meliloti. J. Bacteriol. 191:5890-5900.

Muthukumarasamy, U. G., Kang, K. D., Park, W. T., Jeon, C. Y., Park, Y. S., Cho, S. W., Kwon, J., Song, D. H., and Revathi G. 2007. Enumeration, isolation and identification of diazotrophs from Korean wetland rice varieties grown with long-term application of $\mathrm{N}$ and compost and their short-term inoculation effect on rice plants. J. Appl. Microbiol. 102:981-991.

Oliveira Pinheiro, R., Boddey, L. H., James, E. K., Sprent, J. I., and Boddey, R. M. 2002. Adsorption and anchoring of Azospirillum strains to roots of wheat seedlings. Plant Soil 246:151-166.

O'Toole, G. A., and Kotler, R. 1998. Initiation of biofilm formation in Pseudomonas fluorescens WCS365 proceeds via multiple, convergent signalling pathways: A genetic analysis. Mol. Microbiol. 28:449-461.

Quelas, J. I., Mongiardini, E. J., Casabuono, A., López-García, S. L., Althabegoiti, M. J., Covelli, J. M., Pérez-Giménez, J., Couto, A., and Lodeiro, A. R. 2010. Lack of galactose or galacturonic acid in Bradyrhizobium japonicum USDA 110 exopolysaccharide leads to different symbiotic responses in soybean. Mol. Plant-Microbe Interact. 23:1592604.

Quesada, E., Béjar, V., and Calvo, C. 1993. Exopolysaccharide production by Volcaniella eurihalina. Experientia 49:1037-1041

Ramos, H. J. O., Roncato-Maccari, L. D. B., Souza, E. M., Soares-Ramos, J. R. L., Hungria, M., and Pedrosa, F. O. 2002. Monitoring Azospirillum-wheat interactions using the gfp and gusA genes constitutively expressed from a new broad-host range vector. J. Biotechnol. 97:243-252.

Reis, V. M., Olivares, F. L., and Döbereiner, J. 1994. Improved methodology for isolation of Acetobacter diazotrophicus and confirmation of its endophytic habitat. World J. Microbiol. Biotechnol. 10:401-405.

Reis, V. M., Olivares, F. L., de Oliveira, A. L. M., Reis, F. B., Baldani, J. I., and Döbereiner, J. 1999. Technical approaches to inoculate micropropagated sugar cane plants with Acetobacter diazotrophicus. Plant Soil 206:205-211

Rigano, L. A., Payette, C., Brouillard, G., Marano, M. R., Abramowicz, L., Torres, P. S., Yun, M., Castagnaro, A. P., El Oirdi, M., Dufour, V., Malamud, F., Dow, J. M., Bouarab, K., and Vojnov, A. A. 2007. Bacterial cyclic $\beta-(1,2)$-glucan acts in systemic suppression of plant immune responses. Plant Cell 19:2077-2089.
Rinaudi, L. V., and Giordano, W. 2010. An integrated view of biofilm formation in rhizobia. FEMS (Fed. Eur. Microbiol. Soc.) Microbiol. Lett. 304:1-11.

Rodrigues Neto, J., Malavolta, V. A., and Junior, V. O. 1986. Meio simples para o isolamento e cultivo de Xanthomonas campestris pv. citri Tipo B. Summa Phytopathol. 12:16.

Rodriguez-Navarro, D. N., Dardanelli, M. S., and Ruiz-Sainz, J.E. 2007. Attachment of bacteria to the roots of higher plants. FEMS (Fed. Eur. Microbiol. Soc.) Microbiol. Lett. 272:127-136.

Rouws, L. F. M., Simões-Araújo, J. L., Hemerly, A. S., and Baldani, J. I. 2008. Validation of Tn5 transposon mutagenesis system for Gluconacetobacter diazotrophicus through characterization of a flagellar mutant. Arch. Microbiol. 189:397-405.

Rouws, L. F. M., Meneses, C. H. S. G., Guedes, H. V., Vidal, M. S., Baldani, J. I., and Schwab, S. 2010. Monitoring the colonization of sugarcane and rice plants by the endophytic diazotrophic bacterium Gluconacetobacter diazotrophicus marked with gfp and gusA reporter genes. Lett. Appl. Microbiol. 51:325-330.

Sambrook, J., Fritsch, E. F., and Maniatis, T. 1989. Molecular Cloning. A Laboratory Manual, 2nd ed. Cold Spring Harbor Laboratory Press, Cold Spring Harbor, NY, U.S.A.

Saravanan, V. S., Madhaiyan, M., and Thangaraju, M. 2007. Solubilization of zinc compounds by the diazotrophic, plant growth promoting bacterium Gluconacetobacter diazotrophicus. Chemosphere 66:1794-1798.

Sevilla, M., Burris, R. H., Gunapala, N., and Kennedy, C. 2001. Comparison of benefit to sugarcane plant growth and ${ }^{15} \mathrm{~N}_{2}$ incorporation following inoculation of sterile plants with Acetobacter diazotrophicus wildtype and Nif ${ }^{-}$mutants strains. Mol. Plant-Microbe Interact. 14:358-366.

Skorupska, A., Janczarek, M., Marczak, M., Mazur, A., and Kröl, J. 2006. Rhizobial exopolysaccharides: Genetic control and symbiotic functions, Microb. Cell Fact. 5:7.

Steenhoudt, O., and Vanderleyden, J. 2000. Azospirillum, a free-living nitrogen-fixing bacterium closely associated with grasses: Genetic, biochemical and ecological aspects. FEMS (Fed. Eur. Microbiol. Soc.) Microbiol. Rev. 24:487-506.

Tapia-Hernández, A., Bustillos-Cristales, M. R., Jiménez-Salgado, T., Caballero-Mellado, J., and Fuentes-Ramirez, L. E. 2000. Natural endophytic occurrence of Acetobacter diazotrophicus in pineapple plants. Microb. Ecol. 39:49-55.

Urzainqui, A., and Walker, G. C. 1992. Exogenous suppression of the symbiotic deficiencies of Rhizobium meliloti exo mutants. J. Bacteriol. 174:3403-3406.

Valverde, A., Castro-Sowinski, S., Lerner, A., Fibach, S., Matan, O., Burdman, S., and Okon, Y. 2008. Exopolysaccharide Production and Cell Aggregation in Azospirillum brasilense. Curr. Plant Sci. Biotechnol. Agric. 42:319-320

Vinagre, F., Vargas, C., Schwarcz, K., Cavalcante, J., Nogueira, E. M., Baldani, J. I., Ferreira, P. C. G., and Hemerly A. S. 2006. Shr5: A novel plant receptor kinase involved in plant- $\mathrm{N}_{2}$-fixing endophytic bacteria association. J. Exp. Bot. 57:559-569.

Watnick, P. I., and Kolter, R. 1999. Steps in the development of a Vibrio cholerae El Tor biofilm. Mol. Microbiol. 34:586-595.

Whitfield, C., and Valvano, M. A. 1993. Biosynthesis and expression of cell-surface polysaccharides in gram-negative bacteria. Adv. Microb. Physiol. 35:135-246.

You, C., Lin, M., Fang. X., and Song, W. 1995. Attachment of Alcaligenes to rice roots. Soil Biol. Biochem. 27:463-466.

Yun, M. H., Torres, P. S., Oirdi, M. E., Rigano, L. A., Gonzalez-Lamothe, R., Marano, M. R., Castagnaro, A. P., Dankert, M. A., Bouarab, K., and Vojnov, A. A. 2006. Xanthan induces plant susceptibility by suppressing callose deposition. Plant Physiol. 141:178-187. 